\title{
Cervantes Read by Freud: A Perspective
}

\author{
By Francisco López-Muñoz* \\ Francisco Pérez-Fernández \\ Cecilio Álamo \\ Pilar García-García
}

Sigmund Freud felt very attracted throughout his life by Miguel de Cervantes' works, which led him to become a self-taught of Spanish in order to read Don Quixote. However, Freud cited Cervantes' work very little along his scientific production. Freud's references to Cervantes and his texts and characters can be mostly found in his voluminous correspondence. There are two revealing epistolary collections that can shed light on the subject that concerns us: a collection of letters sent to Martha Bernays during the period between 1882 and 1886 (The Bridal Letters), and another collection (1871-1881), known as The Youth Letters, linked to his friend Eduard Silberstein. All these mentions are limited to two Cervantine texts: Don Quixote and The Dialogue of the Dogs. Freud and Silberstein founded a secret literary society ("Academia Castellana"), and they usually communicated in Spanish. This article examines the link between Freud and Cervantes and provides some details about the possible influence of the works of the classical Spanish writer on the scientific contributions of the author of psychoanalysis. In some paragraphs of Don Quixote there is a clear Freudian symbolism, whereas in the exemplary novel The Dialogue of the Dogs, a methodological development of psychoanalytic interview can be found which would be raised by Freud almost three hundred years later.

\section{Introduction}

Sigmund Freud (1856-1939) is, perhaps, one of the most famous authors in the history of psychology and psychiatry beyond their academic and scientific limits. His contributions have largely transcended these fields, making a decisive contribution to other disciplines such as philosophy, anthropology and humanities. Undoubtedly, Freud is one of the most influential figures of the $20^{\text {th }}$ century. However, his work has been criticized, having being denied its scientific nature by some sectors of the fields of medicine or psychology. These groups have placed it closer to general culture, anthropology or philosophy. In fact, even his greatest creation, psychoanalysis, experienced a process of decay since the middle of the last century, despite its continuous

\footnotetext{
* Professor of Pharmacology, Faculty of Health Sciences, and Director of International Doctorate School at Camilo José Cela University, Madrid, Spain; Research Fellow at "Hospital 12 de Octubre" Research Institute (i+12), Madrid, Spain; and Research Fellow at Portucalense Institute of Neuropsychology and Cognitive and Behavioural Neurosciences, Portucalense University, Porto, Portugal.

${ }^{\dagger}$ Associate Professor of History of Psychology, Department of Psychology, Faculty of Health Sciences at Camilo José Cela University, Madrid, Spain.

* Professor of Pharmacology, Department of Biomedical Sciences, Faculty of Medicine and Health Sciences at University of Alcalá, Madrid, Spain.

${ }^{+}$Honorary Research Professor, Department of Biomedical Sciences, Faculty of Medicine and Health Sciences at University of Alcalá, Madrid, Spain.
} 
reinterpretation in favor of biological and pharmacological new currents that permeated psychiatry from the $1950 \mathrm{~s}^{1}$.

The discussion about the value of Freud's contribution to science and culture does not seem odd, particularly if we consider that Freud was aware of his will of keeping intellectual equidistant positions on both. In February 1896, he confessed to Wilhelm Fliess (1858-1928) that in his youth he knew nothing but the desire for philosophical knowledge, longing that was about to fulfill through psychoanalysis, psychology displacing medicine ${ }^{2}$. In this case, we might wonder then how someone pushed by these young motivations chose to embark on a medical career for which he never felt special predilection, as he admitted in his Autobiography ${ }^{3}$. In this decision, maybe, he was influenced by other instrumental needs, as for example to ensure a suitable future for a Jewish middle-class boy. But the fact that he did not opt for a political or legal career, as many other men in his situation did, tells us also about other intellectual motivations, as can be expected from a book lover and a person interested in the understanding of man's problems, who was stumbled and surprised with the suggestive contribution of Charles Darwin (1809-1882) as other young people were in his time. In fact, Freud, busy and stubbornly concerned about humanistic issues, felt the call of philosophy, but at the same time experienced doubts with the speculative depths used by philosophers and wanted to have a sober scientific training ${ }^{4}$.

\section{Freud and Literature}

The merit of Freud's contributions is enhanced if we consider the tremendous influence of his psychological theories, which many people did not hesitate to refer to as "pseudo-psychological" ${ }^{5}$, on the most important cultural movements of the $20^{\text {th }}$ century, including art and literature. Precisely in relation to literature, the figure of Freud breaks the limits of science and penetrates within the narrative universe. Do not forget, in this regard, that the Austrian psychiatrist was honored in 1930 with the prestigious Goethe Prize for the excellence of his prose in his scientific works: the culmination of a life marked by a deep interest in handwriting that Freud never sidestepped and which began in his teen years. No wonder, then, that all his intellectual approaches were nearly literary reflections that Freud never intended to hide, even if it affected the scientific validation of his work. Sophocles, Shakespeare, Goethe and

1. F. López-Muñoz, and C. Álamo (Eds.), Historia de la Psicofarmacología [History of Psychopharmacology], 3 vols (Madrid: Editorial Médica Panamericana, S.A, 2007); F. LópezMuñoz, C.Álamo, and E.F. Domino (Eds.), History of Psychopharmacology, 4 vols. (Arlington: NPP Books, 2014).

2. S. Freud, Cartas a Wilhelm Fliess [Letters to Wilhelm Fliess] (1887-1904) (Buenos Aires/Madrid: Amorrortu, 2008).

3. S. Freud, Autobiografía [Autobiography] (Madrid: Alianza, 2006).

4. C. Gómez, La realidad y la ilusión: Cervantes en Freud [Reality and Illusion: Cervantes in Freud], An. Sem. Hist. Fil. 24(2007): 195-214.

5. B. Wolman, Teorías y sistemas contemporáneos en psicología [Contemporary theories and systems in psychology] (Barcelona: Martínez-Roca, 1968). 
Dostoyevsky (to name a few recurrent authors in Freud's work) and their characters appear again and again in his writings as explanatory devices, comparison methods, metaphors or examples ${ }^{6}$. In fact, he even came unequivocally to admit that psychoanalysis, as a palpable manifestation of the "real" problems, was ultimately accountable for the riddles posed by poetry ${ }^{7}$.

Moreover, and delving into this issue, a man desirous of success and public recognition as Freud was, had to face very soon the impact of singular paradox implicit in his work, and to which we referred at the beginning: whereas his Studies on Hysteria (1895) motivated a cold reception of the book from his medical colleagues - perhaps, because of its excess style-, the text was applauded by those skilled in literature. This contradiction was noticed by the author too. Freud considered that his records on cases of hysteria actually had more of a literary than a scientific facet, but he also understood that it was dyed firstly to the narrative character of this pathology in terms of nature rather than to his personal and scientific interests ${ }^{8}$.

In fact, clinical cases proposed by the creator of psychoanalysis are worded, according to the scholars of his work and the impressions of the author, as if they were authentic fragments of novels, including the maintenance of a scrupulous respect for the literary conventions of space and time ${ }^{9}$. In this regard, we must insist on a briefly gloss of Freud's deep cultural formation: he was a fan of William Shakespeare (1564-1616), whose work he began to read at age of seven, to the point that he usually cited and recited excerpts from his literary works; he was a translator of John Stuart Mill (1808-1873); read in classical Greek and wrote fluently in Latin. Some authors have wanted to see in the Freudian texts a clear influence not only of philosophers such as Arthur Schopenhauer (1788-1870), Friedrich Nietzsche (1844-1900) and even Immanuel Kant (1724-1804) or Georg Hegel (1770$1831)^{10}$, but also of literary authors, as the French symbolist poets Arthur Rimbaud (1854-1891) and Stéphane Mallarmé (1842-1898), representatives of the German romanticism and, particularly, of Miguel de Cervantes (1547$1616)^{11}$ (Figure 1), to whom Freud always exhibited a very special attraction and who is considered by some experts as a cultural predecessor of Freud ${ }^{12}$.

6. Gómez, An. Sem. Hist. Fil. 24(2007).

7. Freud, Autobiografía, 2006.

8. In this paper, we have used the Complete Works [Obras Completas] of Freud, published in Castilian in 1923 by Biblioteca Nueva (Madrid) and reedited in 1968 S. Freud, Obras completes [Complete Works] vol. I (Madrid, España: Biblioteca Nueva, 1968).

9. E.C. Riley, "Cervantes, Freud and psychoanalytic narrative theory," Modern Lang. Rev. 88(1993): 1-14. See also: J.A. Parr, "Cervantes foreshadows Freud: On Don Quixote's Flight from the feminine and the physical," Bull. Cervantes Soc. Am. 15(1995): 16-25.

10. J. Labastida, "El Quijote lee a Kant, Hegel, Freud y Lacan" ["Quixote reads Kant, Hegel, Freud and Lacan"], in Memorias de la Academia Mexicana de la Lengua, vol XXVII (1997-1999) (Mexico: Academia Mexicana de la Lengua, 2004), 348-365.

11. Even though Cervantes' biography is well known, it is essential here to offer a brief summary. Miguel de Cervantes Saavedra was born in Alcalá de Henares, a Castilian city close to Madrid, on September 29, 1547. He descended from a family of doctors. Fleeing justice, Cervantes moved to Rome at the age of twenty one in order to serve a distant relative, the Cardinal Julio Acquaviva (1546-1574). Later, he became a soldier in the assault troops known as the Tercios (Spanish Navy Infantry), in the service of Philip II, and fought in the 


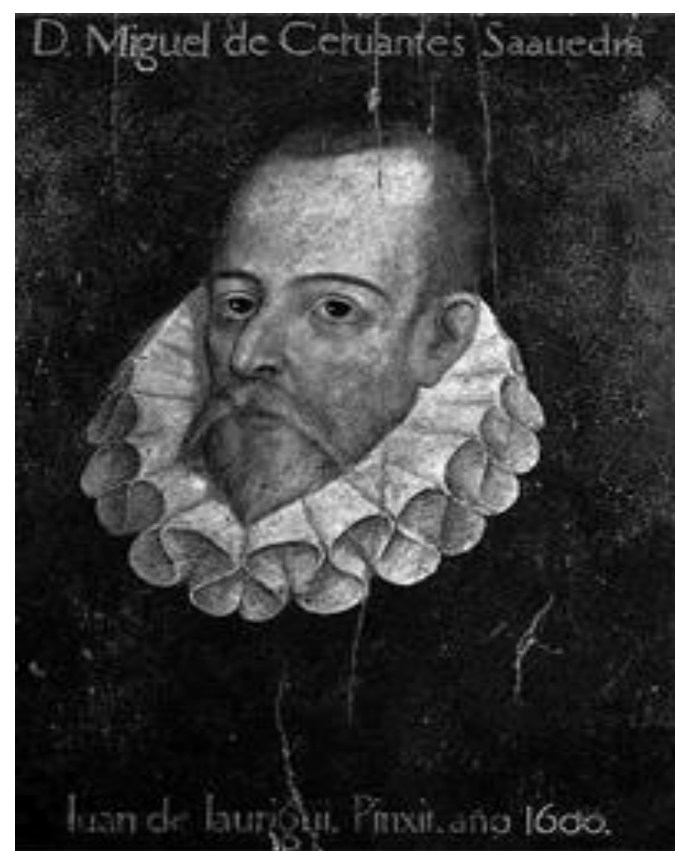

Figure 1. Portrait of Miguel de Cervantes Saavedra according to an oil painting dated 1600 and attributed to Juan de Jáuregui y Aguilar Source: Real Academia Española, Madrid.

When Freud was at an advanced age, he acknowledged the great attraction that he had felt throughout his whole life to the work of Cervantes in a letter to

famous Battle of Lepanto (1571), where he lost the use of his left hand. In 1575 he was captured by Algerian corsairs, and survived five years in the hard Berber prisons of Algiers, until he was released, after four unsuccessful escape attempts, on ransom from his parents and the Trinitarians, a Catholic religious order, and he subsequently returned to his family in Madrid. He worked as a civil servant in the tax ministry and other government agencies. In Esquivias (Toledo), on December 12, 1584, he married Catalina de Salazar y Palacios (1565-1626). Success never accompanied him on his professional (or affective) activities, being imprisoned several times due to irregularities in his tax collection efforts. In 1607, he settled in Madrid, where he lived and worked until his death. Indeed, his literary production is far from prodigious and occurred late in his life, public recognition arriving only in the last decade of his life, and due largely to a single work, Don Quixote [El Ingenioso Hidalgo Don Quijote de La Mancha, 1605]. He published the Exemplary Novels [Novelas ejemplares] in 1613, the Journey to Parnassus in 1614 and, in 1615, the Cervantes' Eight Interludes [Ocho comedias y ocho entremeses] and the second part of Don Quixote. He died in Madrid in 1616 from type II diabetes. The publications on different biographical aspects about Cervantes are very numerous. See, for instance: J. Fitzmaurice-Kelly, Miguel de Cervantes Saavedra. Reseña documentada de su vida [Miguel de Cervantes Saavedra. Documented Review of his life] (1980), http://bit.ly/2Qb mOY7; J. Canavaggio, Cervantes. En busca del perfil perdido [Cervantes. In search of the lost profile] 2nd ed. (Madrid: Espasa-Calpe, 1992); or D. Eisenberg, Vida de Cervantes [Life of Cervantes] (Alicante: Biblioteca Virtual Miguel de Cervantes, 2003).

12. L. Grinberg, and J.F. Rodríguez, "La influencia de Cervantes sobre el futuro creador del psicoanálisis" ["The influence of Cervantes on the future creator of psychoanalysis"] An. Cervantinos, 25-26(1987-1988): 157-174. This attraction to the work of Cervantes is not unique to Freud. There have been many medical professionals, such as the Nobel Prize Santiago Ramón y Cajal (1852-1934), who over the last four hundred years have been captives of immortal Cervantes' novel, reaching influence, according to his notes and autobiographies, in his own life story. 
Luis Lopez-Ballesteros y de Torres (1896-1939) ${ }^{13}$, a translator of scientific work to Castilian. This letter was signed in Vienna and dated in May 7, 1923. In this same letter, the psychiatrist says: "being a young student, the desire to read the immortal D. Quixote in the original cervantino, pushed me to learn, without any teachers, the beautiful Spanish [language]" [sic] ${ }^{14}$. However, note that most of Freud's biographers, such as Ernest Jones and Peter Gay, do not report any relationship with the Spanish language according to the international contacts made by the founder of psychoanalysis during the first third of the 20 th century. Even in the case of Gay ${ }^{15}$, the fact that the first complete and nonGerman edition of Freud's texts was precisely the Spanish one made by LópezBallesteros, ordered by José Ortega y Gasset (1883-1955) and directed by José Ruiz-Castillo (1910-1945), was inexplicably ignored ${ }^{16}$. An oversight that has become a constant among Freud's biographers and critical commentators, to the point that in a recent review of his biography published by Breger ${ }^{17}$ there is no longer allusion made, not even remotely, to the Spanish language or literature, authors or intellectuals. A fact, moreover, surprising when a protobiographer of Freud, the writer Stefan Zweig (1881-1942), did not hesitate in 1931 to offer a vision of the creator of psychoanalysis such as an unregenerate fighter against intellectual wind mills, real or imaginary, that is well described as "quixotic"18.

The question then is, and this is the ultimate goal of this text, whether the interest in linking Freud to Cervantes is, beyond the purely literary passion that the former developed towards the latter, merely an embodied obsession by the Hispanics and "Cervantists" or a true and lasting intellectual bond ${ }^{19}$. Do not forget that, despite its acknowledged passion for the writer born in Alcalá de Henares, Freud never cites him in a formal way throughout his vast scientific production, which could justify the before-mentioned deliberate abandonment. In fact, Freud's references to Cervantes and his texts and characters come mostly from his voluminous correspondence. In this sense, there are two very revealing epistolary collections that can shed light on the subject that concerns us: a) a collection that can already be considered classic, and in which letters are sent to Martha Bernays (1861-1951) ${ }^{20}$ (Figure 2) during the period between

13. This letter is well known to be headed the volumes of the famous Spanish translation of the Freud' Complete Works, ed. Biblioteca Nueva, first in no German language.

14. S. Freud, Obras completas, 1968, 9.

15 P. Gay, Freud. Una vida de nuestro tiempo [Freud. A life of our Time] (Barcelona: Paidós, 1989).

16. H. Carpintero and M.V. Mestre, Freud en España [Freud in Spain] (Valencia: Promolibro, 1984).

17. L. Breger, Freud. El genio y sus sombras [Freud. The genius and its Shadows] (Buenos Aires: Argentina: Ediciones B, 2001).

18. S. Zweig, La curación por el espíritu [Healing by the Spirit] (Barcelona: Editorial Acantilado, 2006).

19. F. López-Muñoz, G. Rubio, C. Álamo, and P. García-García, "A propósito de la locura del hidalgo Alonso Quijano en el marco de la medicina española tardorrenacentista" ["On the subject of the madness of the hidalgo Alonso Quijano in the frame of the Spanish medicine of the late Renaissance"], An. Psiquiatr. 22(2006): 133-145.

20. S. Freud, Cartas a la novia [The bridal Letters] (1882-1886) (Barcelona: Tusquets 1973). 
1882 and 1886, and b) another collection of more recent publication in Spain ${ }^{21}$, whose main contact is his friend Eduard Silberstein (1856-1925) and to which we will devote more attention due to its references to Miguel de Cervantes (Figure 3). These letters were written between 1871 and $1881^{22}$.

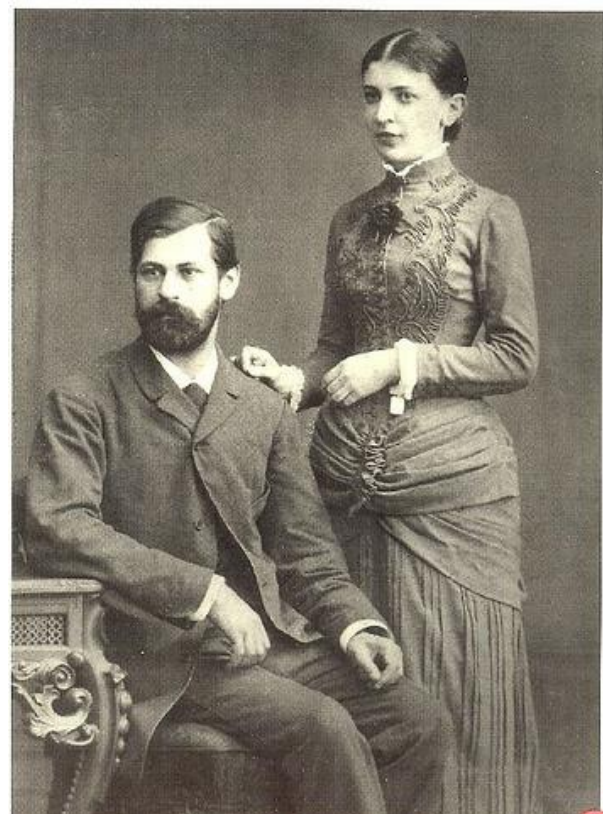

Figure 2. Sigmund Freud and his bride Martha Bernays in 1885 Source: Sigmund Freud Museum, Wien

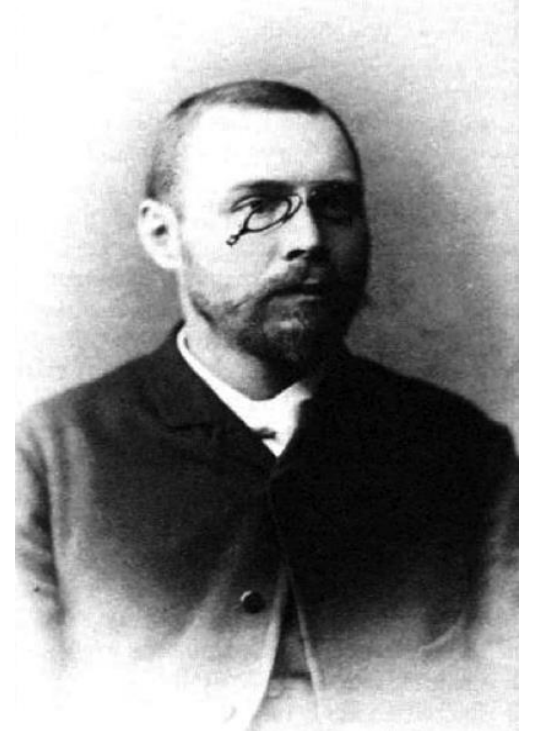

Figure 3. Freud's Childhood Friend, Eduard Silberstein, in his Days as a Student

Source: Formaçao Freudiana. As Cartas para Eduard Silberstein, 2012. http://bit.ly/2ripHiA.

21. S. Freud, Cartas de juventud [The youth letters] (1871-1881) (Barcelona: Gedisa, 1992). 22. In fact, it was in 1881, when Freud received his Ph.D. 
According to Chavez ${ }^{23}$, we find in Freud's texts (including his letters) thirteen explicit mentions to Cervantes and his works: five of them in Complete Works, five references in the letters to Martha Bernays, and another three in the correspondence with Silberstein. All these mentions are limited to two Cervantine texts, which we will subsequently address: Don Quixote and The Dialogue of the Dogs.

\section{The "Spanish Academy" ["Academia Española"]}

On April 28, 1885 Freud wrote to Martha Bernays:

"I destroyed all my notes and letters from the last fourteen years, scientific abstracts and manuscripts of work. I have only saved the family letters [...]. I cannot age or die worried about who will get into the old papers" $^{24}$.

This would not be the only time it happened, since Freud would repeat the operation of documentary destruction in 1907, and the act decisively limited the amount of existing information about the period of his adolescence and early adulthood. Fortunately, much of his epistolary partners chose not to be so dramatic with their past, which minimized to a certain extent Freud's effort to conceal. And this is how we can understand the interest of the young Freud in the life and work of Miguel de Cervantes, since the publication of the letters written between December 1871 and January 1881 do confirm this.

The fact is that Sigmund Freud maintained during his adolescence a close relationship with a schoolmate, a Romanian born in Jassy, educated in an Orthodox Jewish family, called Eduard Silberstein ${ }^{25}$. Their relationship was close, to the point that they decided to self-learn Spanish, for which they founded a secret literary society which they called "Academia Castellana" (AC) or, on other occasions, "Academia Española" (AE), composed at all times only by its two founding members ${ }^{26}$. The Charter of the AE, and its statutes must have actually existed, as often throughout these years correspondence both Freud and Silberstein allude to such documents. Unfortunately, they are likely to have remained in power of the former who would have destroyed them so that they have not reached us. In any case, the epistolary collection from his youth consists of seventy five letters, including postcards and short messages written by Freud. Of them, twenty two are written entirely in Castilian and

23. C. Chávez, "El Quijote y El coloquio de los perros: origen inconsciente del psicoanálisis" ["Don Quixote and The colloquium of dogs: unconscious origin of psychoanalysis"], in XIX Coloquio Cervantino Internacional. El Quijote, perspectiva del siglo XXI (Guanajuato, Mexico, November 4-8, 2008).

24. S. Freud, Cartas a la novia, 1973, 53-54.

25. E. Jones, Vida y obra de Sigmund Freud [Life and works of Sigmund Freud] (Buenos Aires: Nova, 1962). See also: J. Beá, and V. Hernández, "Don Quixote: Freud and Cervantes," Int. J. Psychoanal. 65(1984): 141-153.

26. E.C. Riley, "Cipión Writes to Berganza in the Freudian Academia Española," Bull. Cervantes Soc. Am. 14(1994): 3-18. Also: J.A. Parr, Cervantes foreshadows Freud, 1995. 
thirteen partially. Among them there are some of intimate and emotional content. This way, for example, Freud reaffirms his Jewish origins and even reveals his feelings about his first adolescence love at the age of sixteen, both in Castilian. The scientific, philosophical and literary interests and aspirations of the young Freud are also reflected in Castilian, as well as some other varied opinions. The originals from all these documentary materials are now preserved in the Library of the Congress of the United States, more specifically in box number 3 of the collection entitled Sigmund Freud papers, circa 6th Century BC -1998 (Id. MSS39990) ${ }^{27}$.

One of the Exemplary Novels $(1613)^{28}$ from Cervantes, The Dialogue of the Dogs, must have particularly impressed the two members of the "Academia", since they adopted as a pseudonym or codename the name of its protagonists, the two $\operatorname{dogs}^{29}$ talking lying on the hospital of Valladolid (Figure 4). Thus, Freud became "Cipión [Scipio]" and Silberstein became "Berganza". Around this topic and in February $7^{\text {th }}, 1884$, Freud wrote to Martha Bernays:

"Today Silberstein has come to see me again. He shows the same affection for me as before. We were friends at a time when friendship was not taken as a sport or an advantage, but as a need to live with your friend. We studied together the Spanish language and had our own mythology and secret names taken from a dialogue by the great Cervantes. In our Spanish reading book we once found a philosophical-humorous dialogue between two dogs, who are sitting contemplative in front of a hospital door, and we appropriated their names, both in written and oral communication" ${ }^{30}$.

Indeed, most of the letters written by Freud and addressed to Silberstein start with a "querido Berganza" ("dear Braganza") and end with a "tu fiel Cipio, pero en el Hospital de Sevilla" [sic] ("your faithful Cipio, but at Seville's Hospital"), or "quedo su atento servidor Cipion" [sic] ("remaining your attentive servant, Cipion"). At other times, Freud defined himself as "miembro vitalicio de la famosa A.E." (life member of the famous A.E). Also use acronyms like "M.D.L.A.E." ("Miembro de la Academia Española"; "Member of the Spanish Academy"), "P.E.E.H.D.S." ("Perro en el Hospital de Sevilla"; "Dog at Seville's Hospital"), and "E.D.L.S.N.Y.P." (very possibly "En Dos

27. http://bit.ly/2rQu2fL.

28. See: M. Cervantes, Novelas ejemplares, II [Exemplary Novels, II], H. Sieber (ed.). Madrid: Cátedra, 2003).

29. Some authors considered Freud and Silberstein's selection of the Cervantine "dogs" as a rebellion against the derogatory term used in the contemporary Europe of Cervantes to designate Jews ("Jewish dog"), all in a period in which the process of racial segregation against this population in Central Europe was germinating and which would culminate during the Third Reich: M.R. Moreno, "Un original coloquio. Desde el Jardín de Freud" ["An original colloquium. From Freud`s Garden"], Rev. Psicoanál. 6(2006): 272-281.

30. Freud, Cartas a la novia, 1973, 36-37. 
Lenguas Sin Nación Y Patria"; "In Two Languages With No Nation Or Homeland") $)^{31}$.

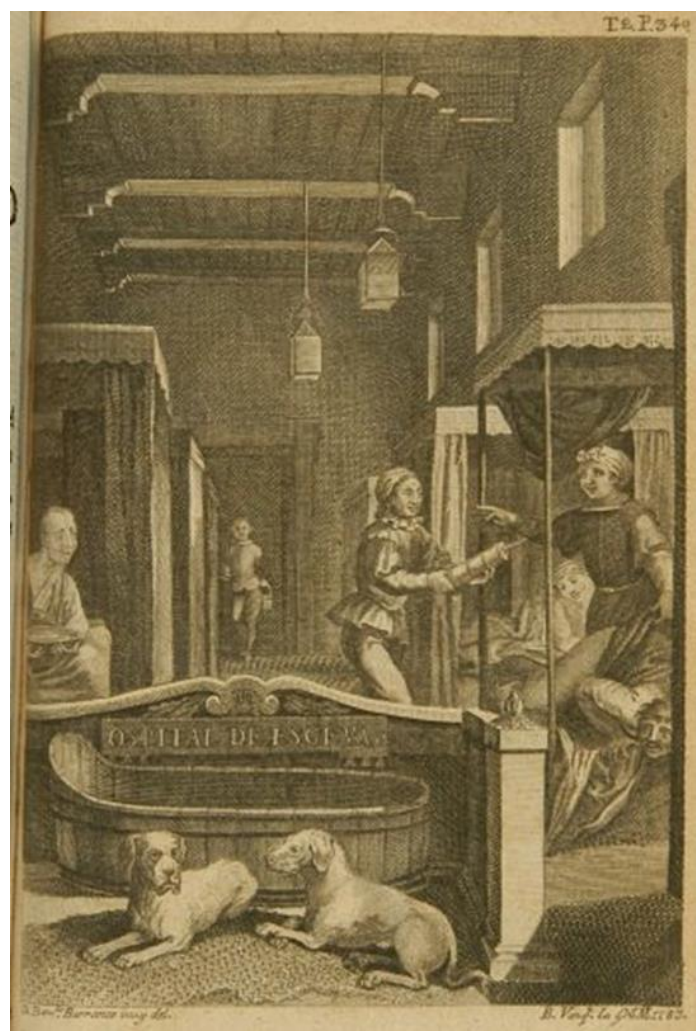

Figure 4. Illustration in the Dialogue of the Dogs by J. Ximeno and Barranco Engraved in Copper by Brieva, Ximénez Vázquez, Moreno Tejada, and Others Source: Cervantes, M. Novelas Ejemplares (Madrid: Don Antonio de Sancha, 1783).

\section{The Man from La Mancha [The Ingenious Gentleman Don Quixote of La Mancha]}

The Ingenious Gentleman Don Quixote of La Mancha (Imprenta de Juan de la Cuesta, Madrid, 1605) (Figure 5) by Miguel de Cervantes ${ }^{32}$ is, for many specialists, the starting point of modern novel, being considered also as one of the best works in the history of literature. Indeed, a few years ago the Nobel Institute and the Norwegian Book Club made public the results from a survey conducted on a sample of one hundred writers from fifty four countries in which they were asked for the best literary works of all time; Don Quixote was chosen on first place, with fifty percent more votes than the second, In Search of Lost Time, by Marcel Proust (1871-1922) ${ }^{33}$.

31. Riley, Modern Lang. Rev., 88 (1994).

32. M. Cervantes, Don Quijote de la Mancha [Don Quixote of La Mancha], F. Rico (ed.) (Madrid: Santillana, 2004).

33. R. Corral-Márquez, and R. Tabarés-Seisdedos, "Aproximación psicopatológica a El Quijote (según la nosología psiquiátrica actual)" ["Psychopathological Approach to Don Quixote (according to current psychiatric nosology)"], Rev. Asoc. Esp. Neuropsiquiatr. 22(2003): 27-57. 


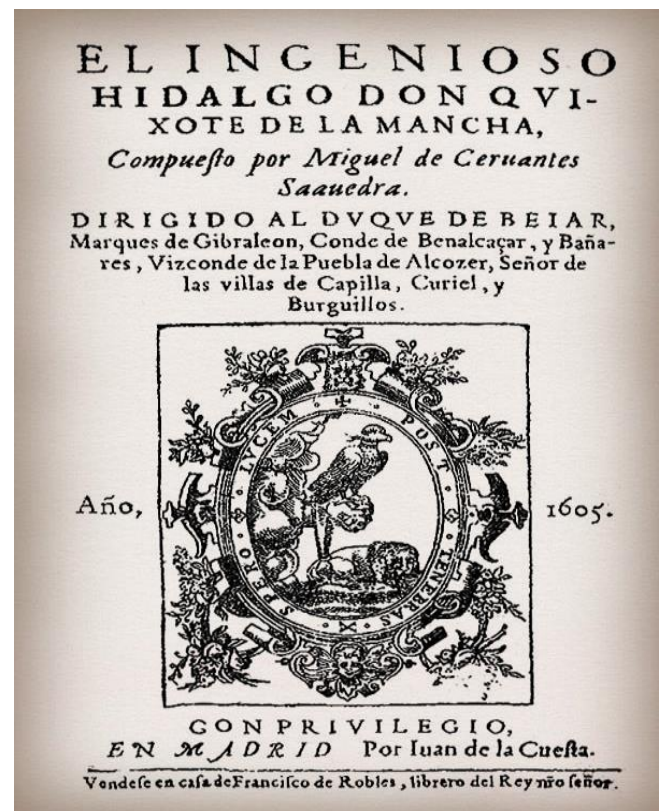

Figure 5. Frontispiece of the "Princeps" Edition of Don Quixote (1605), Dedicated to the Duke of Béjar and Edited by the Madrilenian Press of Juan de la Cuesta, Located in Atocha St.

Source: Cervantes, M. El ingenioso hidalgo Don Quixote de la Mancha (Madrid: Juan de la Cuesta, 1605).

Freud's relationship with Don Quixote is later and less important in scientific literature regardless of the exegetical efforts made by the interpreters of Freud's works since, as noted above, its impact on his published works or in his epistolary communications is much lower. However, Freud himself acknowledged several times during the last years of his youth his interest in this book, as it is later said in the letter sent to López-Ballesteros.

It is known then, that Freud certainly read Don Quixote during the years prior to his marriage to Martha, and he read it in the original Castilian. Despite being masterfully written, he would consider that in the frame of the antifemale culture of the 19th century it was not a recommended reading for women. However, as it has already been said, Cervantes' novel and its characters barely appear in the Freudian texts. In one of the letters of the "Academia Española" -dated January 30 ${ }^{\text {th }}$, 1875-, Freud mentions the character Dr. Pedro Recio de Tirteafuera ${ }^{34}$, and also expresses his intention to gift his personal copy of Don Quixote to Silberstein for his birthday. This wish of Freud's should have grave consequences between the two friends because in a previous letter-dated on December $11^{\text {th }}, 1874$ - Freud had written:

"I connect this with the comment about your strange refusal to accept on December $27^{\text {th }}$ of this year a book [Don Quixote, certainly] as a gift. In principle, I cannot deny that there is an A.E. article (prohibiting gifts

34. Cervantes, Don Quijote de la Mancha, 2004, II-XLVII. In the quotations of Cervantes' work, Don Quixote, the first Roman numerals refer to the first or second part of it, and the second Roman numerals are related to the chapter. 
on the occasion of birthdays); but the historians from the A.E. remember that the article was violated not long ago by a member currently residing in Leipzig, and logicians and jurists of the A.E. deducted from this and declared as ratified that the mentioned article also shall be suspended for the other member" ${ }^{35}$.

Anyway, ignoring whether Silberstein finally agreed, we found that Freud also mentions Cervantes along the correspondence about the authorship of The Traffic of Algiers (1582) -on March $7^{\text {th }}$, 1875- and again, with other Spanish authors as Fernán Caballero (1796-1877) pseudonym adopted by Cecilia Böhl von Faber, and Ramón de Mesonero Romanos (1803-1882), in another letter dated on August $20^{\text {th }}, 1873^{36}$.

We ignore if Freud's first reading of Don Quixote was very deep, but it is known that possibly in the summer of 1883 , at the age of twenty seven, he could have made a further re-reading of the book. It could be evidenced by the frequent comments about the novel made in his correspondence with Martha Bernays during the months of August and September that year. To illustrate this point, we can quote a letter to Martha dated on August $22^{\text {nd. : " }[. . .] ~ I ' m ~ r e a d i n g ~ a ~}$ lot, using much of the day for this. For example, I am now consumed by $D$. Quixote [...] and more focused on him than on the anatomy of the brain"37.

In another of those letters, significantly, Freud identifies himself with Don Quixote, saying that "we are noble knights who went through the world trapped in a dream". This connects his person in a certainly unique way, with the personal reading Stefan Zweig had about Freud, and links notably with later proposals such as Wolman's:

"They could not help but admire [both detractors and supporters] the great moral courage of Freud, who, he was frank and honest about the most controversial issues, despite the pressures and social taboos. [...] He was anything but conservative and opportunistic, and had the courage to admit his mistakes and drastically revise his theories, even completely transforming them in some aspects." 38

The influence of reading Don Quixote while Freud was being educated in the neuropsychiatric field, could have been decisive both for the future of the founder of psychoanalysis and his theory ${ }^{39}$. The novel reflects, like any other work does, the conflict between reality -Sancho Panza- and fantasy -Don Quixote-, a conflict in which Freud himself was completely immersed. However, in his scientific production, the references to Don Quixote are very scarce. For example, in a footnote of Jokes and Their Relation to the Unconscious $(1905)^{40}$, Freud turns to Don Quixote, seeing him as a "big

35. Freud, Cartas de juventud,1992), 126-127.

36. Ibid.

37. Freud, Cartas a la novia, 1973, 17.

38. Wolman, Teorías y sistemas contemporáneos, 1968, 236.

39. Grinberg and Rodríguez, An. Cervantinos, 25-26(1987-1988).

40. S. Freud, El chiste y su relación con lo inconsciente [Jokes and Their Relation to the Unconscious] (Madrid: Alianza, 1905-2012), 307. 
boy" subjected to idealism, in order to illustrate the loss of compassion as the origin of this practice. Also in Totem and Taboo (1913) $)^{41}$, inspired by the biological evolutionism of Charles Darwin and the social evolutionism of James George Frazer (1852-1941), Sancho Panza is chosen to refer to the aggressive and ambivalent treatment which is given to the sovereign. Finally, Sancho Panza is also mentioned in a footnote in the book Psychopathology of Everyday Life (1901) ${ }^{42}$. In this quote, Freud narrates an episode of Don Quixote in which the squire has to administer justice as governor of the island Barataria in a case of rape. Freud says that the ingenious sentence of Sancho Panza in relation to the raped woman is psychologically unfair. Sancho compensates her with a bag full of coins that he takes from the man and as soon as the woman is gone, he gives him permission to run after her and to recover his bag. The woman boasts of the evildoer because he was not able to seize the bag, and Sancho says: "If you had shown the same breath and courage, or even less than half of them, to defend this bag as to defend your body, not even the forces of Hercules would have taken you"43.

All these are interesting details if we take into account that the ongoing struggle of the individual, whose desire is subjected to the principle of reality, is such a deeply psychoanalytic matter that Don Quixote, therefore, can be read as the conflict of a revolutionary Alonso Quijano who has understood a complex idea:

"In order to prevail over reality, dreaming is another different and new reality [...]. We all may become crazy like him. Perhaps only when that happens, when we all men dream and act at the same time, reality will be transformed" 44 .

\section{The Dialogue of the Dogs: An Advance?}

The Dialogue of the Dogs ${ }^{45}$, the last of the Exemplary Novels written by Miguel de Cervantes, is inserted into another text: The Novel of the Deceitful Marriage. In the latter, the sub-lieutenant Campuzano promises discharged soldier Peralta the narration of a series of events that go beyond "imagination, as they lie far apart from the terms of nature" ${ }^{46}$. Campuzano, who is taken to the Hospital of the Resurrection to be treated for a venereal disease, acts as a third indirect actor in the dialogue, hearing the nocturnal conversation of both dogs, which are prostrated at the foot of his bed ${ }^{47}$. As a consequence, The Novel

41. S. Freud, Totem y tabú [Totem and taboo] (Madrid: Alianza, 1913-2013), 73.

42. Freud, S. "Psicopatología de la vida cotidiana" ["Psychopathology of everyday life"], Obras completas, vol 3, XX (Madrid: Biblioteca Nueva, 1905-1997).

43. Cervantes, Don Quijote de la Mancha, 2004, II-XLV.

44. Labastida, Memorias de la Academia Mexicana de la Lengua, 2004, 365.

45. The original title of the work is Coloquio que pasó entre Cipión y Berganza, perros del Hospital de la Resurrección [Colloquium that happened between Cipión and Berganza, dogs of the Hospital of the Resurrection].

46. Cervantes, Novelas ejemplares, 2003, 292.

47. Riley, Modern Lang. Rev. 88(1993), notes that there is no evidence about Freud reading both novels (The Deceitful Marriage and The Dialogue of the Dogs). Possibly he 
of the Deceitful Marriage portrays the confrontation between reality and fantasy, which is one of the central themes of Don Quixote (1605) and an issue that later worried Freud on his way to psychoanalysis. Hence, the connection between the novel and this central topic gives a very interesting detail to the fact that it called Freud's attention ${ }^{48}$.

There is a significant and persistent mistake that Freud makes in reference to the context of this exemplary novel by Cervantes: locating the dogs' conversation in Seville instead of Valladolid as it is narrated by Cervantes. Some authors attribute this to a misreading by Freud, back then in his early years learning Spanish, because in the conversation between both animals the city of Seville is brought up many times. Also, this can be due to an incomplete reading, as it is only said at the end of the narration that the conference between the dogs takes place in Valladolid ${ }^{49}$. The hypothesis of a fragmentary reading is more plausible if we consider the previously mentioned comment by Freud in his letter to Martha Bernays in February 1884. There, he spoke about a "Spanish book of readings" which certainly should include excerpted texts from different works and authors.

Despite this contextual error, Freud's attraction to Seville is evident. In one of these letters, partly written in Castilian, dated March $7^{\text {th }}, 1875$, and pretentiously titled "Parte Oficial. Cosas de la Academia Española o Castellana" ("Official Report. Stuff about the Spanish or Castilian Academy"), the young Freud writes:

"The introduction of these terms in the official S.A. style, terms that are not new, but old and well known and deserve to be taken for use by the m.d.l.A.E. Call the S.A. members "dogs," which is the highest title that they do have and will ever have, call "Seville" the world where they are and call Seville's Hospital the country they live in, i.e. Germany. Finally, call "Cerra" their whereabouts (or if other word which means "Dicke" and which the famous Cervantes has used in the place you known, should that the other word be). This way the m.d.l.A.E. should never say about someone "has died," but he has left Seville, should never say he has left Germany but he has left Seville's hospital, and should never say he has traveled in Germany, from Vienna to Berlin, but say he has moved out the cerra. Call Vienna by another name and so moreover Berlin, but the names I do not want to propose, I let you propose them, live a thousand and two hundred years and be two thousand years maintained, as your D. Cipión wants it". [sic $]^{50}$.

The typical symbolism found in the Freudian texts as well as his interest in style, are already clear in this writing from his adolescence. It shows us a Freud with an archaic management of the Spanish language that he would never

just read the last, because, otherwise, the psychoanalytic game would have been much greater (two pairs of analysts and analysands).

48. Gómez, An. Sem. Hist. Fil. 24(2007): 195-214.

49. Riley, Modern Lang. Rev. 88(1993); Parr, Bull. Cervantes Soc. Am. 15(1995).

50. Freud, Cartas de juventud, 1992, 151. 
abandon throughout his life and it clearly reflects both the means of acquisition and his purpose ${ }^{51}$.

The possibility that this novel by Cervantes had somehow influenced the development of Freud's hypothesis has been demonstrated by several authors $^{52}$. In this sense, it is curious that Freud adopts in the A.C. the role of Cipión or the "listener" as a driving and authoritarian force in the exchange of letters, a task to which subsequently would provide maximum relevance in his therapeutic creation; psychoanalysis. Moreover, in an interesting study, Stanko Vranich ${ }^{53}$ explains that Cipión, the dog created by Cervantes, exercised the role of the therapist, listening to the stories that the dog Berganza tells in a way of catharsis. In fact, Berganza is presented as a product of a "sick society": victim of abandonment, abuses and all kinds of traumas, culminating in a deep conflict about his own identity and origins. Cipión, in his role as Berganza's therapist raises a series of questions to generate a flow of associations. One can grasp a psychoanalytic methodology in the proceedings of Cipión: "Talk until dawn, or until we are senses; I will listen very willingly, without stopping you but when I see it is necessary" ${ }^{\text {54 }}$. This interpretation of the matter is very similar to another, offered by recent studies, such as the one from Gómez who adventures: "Berganza is fundamentally the speaker, while Cipión -Freud, in his correspondence with Silberstein- is the listener and the person that occasionally encourages him to continue" ${ }^{25}$.

Meanwhile, Riley says that this assumption is unfounded and conjectural. In his opinion, the text by Cervantes and the psychoanalytic therapy share only the terms of its narrative theory, which seems to appear in the structure of the dialogue between Cipión and Berganza ${ }^{56}$. However, the juvenile correspondence between Freud and Silberstein, in which both adopt the unambiguous identity of Cervantes' dogs, is interpreted by Riley as a "proto- psychoanalysis" prior to the adult and properly psychoanalytic relationship between Freud and Wilhelm Fliess. Finally, in the same sense, Grinberg and Rodríguez have postulated that this relationship or youth "dialogue" between Freud and Silberstein is the first of a series of psychoanalytic -or psychoanalytical- sequential relationships ${ }^{57}$ : Freud-Martha, Freud-Breuer, Freud-Fliess -consummation of psychoanalytic technique-. For the referred authors, the final stage of these relations was the Freud-Freud self-communication or the great dialogue of self-analysis.

\section{The Interpretation of Cervantes's Figures' Madness}

Freud was not the first psychiatrist interested in the texts of Cervantes (nor the last). From the moment that psychiatry was established as a medical

51. Gómez, An. Sem. Hist. Fil. 24(2007).

52. Grinberg and Rodríguez, Cervantinos, 25-26(1987-1988): 157-174.

53. S.B. Vranich, "Sigmund Freud and 'the case history of Berganza': Freud's psychoanalytic beginnings," Psychoanal. Rev. 63(1976): 73-82.

54. Cervantes, Novelas ejemplares, 2003, 302.

55. Gómez, La realidad y la illusion, 2007, 203.

56. Riley, Modern Lang. Rev. 88(1993): 1-14.

57. Grinberg and Rodríguez, An. Cervantinos, 25-26(1987-1988): 157-174. 
specialty in some countries from the eighteenth century, physicians and particularly psychiatrists, have undergone Cervantes' work to a continuous examination with professional criteria, in order to catalog Don Quixote, in general terms, as mentally ill, according to what Psychiatry manuals of each period show about psyche diseases ${ }^{58}$. Figure 6 shows some of the artistic characterizations of Alonso Quijano's madness published in various historical editions of this masterpiece of literature.
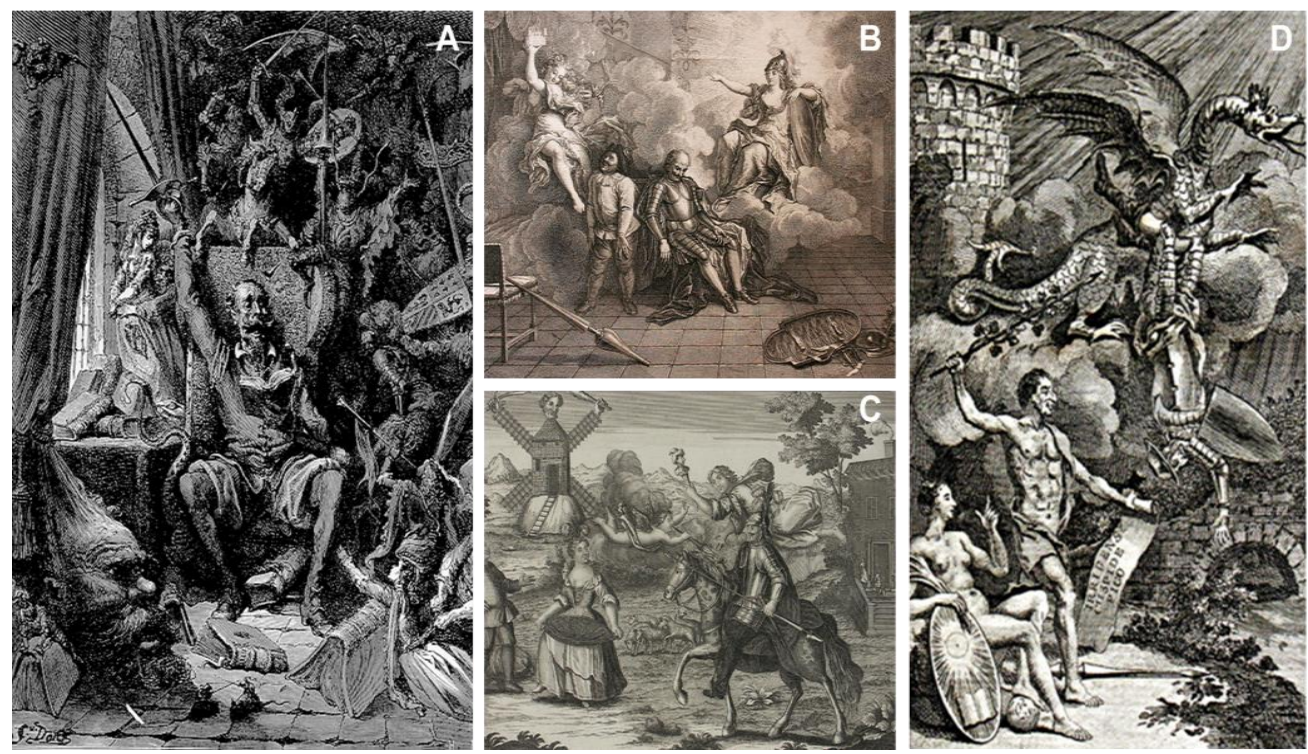

Figure 6. The Madness of Don Quixote in Art.

A: Famous drawing by Gustave Doré (engraved by Henri Pisan) entitled Don Quixote reads his chivalric books, illustrating the Preface of the French edition of Don Quixote. B: Engraving by Charles Nicolas Cochin entitled Don Quichotte est delivré de sa Folie par la Sagesse and published in Les aventures de Don Quichotte.

C: Engraving by an anonymous author carried out on a drawing of Charles Antoine Coypel, entitled Madness and love lead to Don Quixote.

D: Engraving entitled Allegory of madness and wisdom, based on a drawing by Samuel Wale, for an English edition of Don Quixote.

Sources: A: Cervantes, M. L'ingénieux hidalgo Don Quichotte de la Manche (Paris: Hachette, 1863); B: Cervantes, M. Les aventures de Don Quichotte (Paris: Louis Surugue, 1724); C: Les aventures de Don Quichotte (loose prints) (Paris, 1725-1750); D: Cervantes, M. The history of the renowned Don Quixote de la Mancha (London: J. Cooke, 1774).

58. H. Couleon, "L'étrange folie de Don Quichotte. Cervantes et la psychiatrie" ["The strange madness od D. Quixote. Cervantes and Psychiatry"] Ann. Méd-Psychol. 122(1964): 555566; D. Barbier, Don Quichottisme et psychiatrie [Don Quixotism and psychiatry] (Paris, Privat, 1987); F. Alonso-Fernández, El Quijote y su laberinto vital [The Quixote and his vital labyrinth] (Barcelona: Ed. Anthropos, 2005a); D. Gracia, "Discretas locuras. Variaciones en torno al tema de la locura de Don Quijote" ["Discreet foolishness. Variations around the subject of the madness of Don Quixote"], in III y IV Centenario de El Quijote en la Real Academia Nacional de Medicina (Madrid: Ed. Real Academia Nacional de Medicina, 2005), 139-158; L. SánchezGrangel, "Lectura médica de El Quijote" ["Medical Reading of Don Quixote"], in III y IV Centenario de El Quijote en la Real Academia Nacional de Medicina (Madrid: Ed. Real Academia Nacional de Medicina, 2005), 159-73; López-Muñoz et al. An. Psiquiatr, 22(2006): 133-145. 
The famous Philippe Pinel (1755-1826), one of the founders of "scientific psychiatry," is one of the first physicians who studied the madness of Don Quixote. In 1801, Pinel published his most famous work, Traité medicophilosophique sur l'alienation mentale ou la manie [Medical-philosophical treatise on mental alienation or mania], in which he describes for the first time a mental disorder called "monomania," characterized by the development of delusional and obsessive ideas. Precisely, in order to clinically illustrate this disorder, Pinel turns to Don Quixote, of whom an "admirable description of monomania" can be done. Pinel was followed in his psychiatric analysis by many clinicians of the nineteenth century. For example, his disciple Jean Etienne Esquirol (1772-1840) who developed the concept of mania and established for Alonso Quijano the diagnosis of "folie raisonnante," which is a subtype of mania without intellectual deficit. In Spain, Antonio Hernandez Morejón (1773-1863) presented in his work Bellezas de medicina práctica descubiertas en el Ingenioso Hidalgo Don Quijote de La Mancha published in 1836 a complete clinical history of Don Quixote, who is described as choleric and melancholic ${ }^{59}$. Most of Don Quijote's path biographers have agreed, at least in the initial stages, on the diagnosis of monomania, to which some added a component of aggrandizement and erotomania ${ }^{60}$. However, from the Kraepelian postulates, the diagnosis evolved into a paranoid disorder. During the first third of the twentieth century, Ernst Kretschmer's (1888-1964) psychosomatic theories in relation to mental disorders enjoyed great popularity among clinicians. Among the Spanish authors, José Goyanes Capdevila (18761964) wrote in 1932 a work entitled Tipología del Quijote. Ensayo sobre la estructura psicosomática de los personajes de la novela ${ }^{61}$, that was defended in a lecture in 1934 at the Faculty of Medicine of the University of Paris, where he diagnosed Don Quixote's disorder as delusions of interpretation or paranoia. After the arrival of the DSM, the madness of Alonso Quijano could fit into the diagnostic criteria of "delusional disorder": delusions of grandeur in minority conjunction with ideas of persecution (the use of "charmers" is always present), defense, or chaste eroticism ${ }^{62}$. The acceptance of these delusions and grandeur ideas by Sancho Panza makes some authors extend the knight's mental disorder to his squire, speaking of a "folie à

59 A. Hernández Morejón, Bellezas de medicina práctica descubiertas en el Ingenioso Hidalgo Don Quijote de La Mancha [Beauties of practical medicine discovered in the Ingenious Hidalgo Don Quixote of La Mancha] (Madrid: Imprenta de Tomás Jordán, 1836).

60. E. Pi i Molist, Primores de don Quijote en el concepto médico-psicológico y consideraciones generales sobre la locura para un nuevo comentario de la inmortal novela [Primors of Don Quixote in the medical-psychological concept and general considerations on insanity for a new commentary on the immortal novel] (Barcelona: Imprenta Barcelonesa, 1886).

61. J. Goyanes Capdevila, Tipología de El Quijote. Ensayo sobre la estructura psicosomática de los personajes de la novela [Typology of Don Quixote. Essay on the psychosomatic structure of the characters of the novel] (Madrid: Imprenta S. Aguirre, 1932).

62. R. Royo Villanova, "La locura de Don Quijote. Discurso de apertura de la Academia Médico Quirúrgica aragonesa, 1905" ["The madness of Don Quixote. Opening speech of the Aragon Medical Surgical Academy, 1905]" in III y IV Centenario de El Quijote en la Real Academia Nacional de Medicina (Madrid: Ed. Real Academia Nacional de Medicina, 2005), 75-104. 
deux" disorder ${ }^{63}$. Affective disorders can also be identified along the entire quixotic trajectory of Alonso Quijano (the melancholy nuance of the title "Knight of the Sorrowful Countenance" is more than obvious). In a recent approach to the study of madness in the great work by Cervantes, AlonsoFernández says that "Don Quixote is a psychopathological novel, carried out by a mentally ill", and that the pathology of Quijano would fit within the diagnostic criteria for bipolar disorder ${ }^{64}$.

The use by Cervantes of madness as a literary device is not limited to the description of his universal character, Don Quixote, but rather a frequently used tool throughout his life's work. In Don Quixote many crazy stories are narrated: Cardenio, the "Roto" (Zooanthropy); Basilio (reactive depressive episode as a result of a love rejection); Anselmo, the "Rico" (neurotic depression ${ }^{65}$. The prologue to the second part of this same novel relates two short crazy stories: the Fool of Seville and the Fool of Cordoba, both of which reliably reflect psychiatric models of the time as social elements under derision and abuse, and that would respond to a possible diagnosis of residual psychotic disorders, so called "innocent crazies" ${ }^{166}$. Finally, the mad character is used in the Exemplary Novels, as in The Jealous Extremaduran (pathological jealousy), or the The Licentiate of Glass (partial automorphosis delirium or a prototypical case of hysteria where a reasoning judgment remains), another example of "crazy lucid", as Alonso Quijano, in line with the Erasmians postulates ${ }^{67}$. From the perspective of current psychiatry, the symptomatological manifestations described in the Exemplary Novel The Dialogue of the Dogs in relation to witches' ointments could perfectly fit within the diagnostic criteria for substance use disorders (hallucinogen intoxication delirium or hallucinogen-induced psychotic disorders $)^{68}$.

63. R. Tabarés-Seisdedos, and R. Corral-Márquez, "Miguel de Cervantes, 1647-1616," Am. J. Psychiatr. 158(2001): 1392.

64. Alonso-Fernández, El Quijote y su laberinto vital, 2005 a.

65. J. M. Bailón, "Un modelo de depresión neurótica en la obra de Cervantes: 'El curioso impertinente'" ["A model of neurotic depression in the work of Cervantes: 'El curioso impertinente'"], in Actas del II Congreso Internacional de la Asociación de Cervantistas (Naples: Sociedad Edítrice Intercontinentale Gallo, 1995). See also: F. López-Muñoz, C. Álamo and P. García-García, "Locos y dementes en la literatura cervantina: a propósito de las fuentes médicas de Cervantes en materia neuropsiquiátrica" ["Crazy and demented in the Cervantes literature: about the medical sources of Cervantes in neuropsychiatric matter"] Rev. Neurol. 46(2008), 489-501.

66. J. M. Bailón, La Psiquiatría en El Quijote. El diagnóstico de ayer y de hoy [Psychiatry in Don Quijote. The diagnosis of yesterday and today] (Barcelona, Ars Medica, 2006). Also: López-Muñoz et al., Rev. Neurol. 46(2008), 489-501.

67. F. Alonso-Fernández, "Dos especies psicopatológicas: Don Quijote y el licenciado Vidriera" ["Two psychopathological species: Don Quixote and Licentiate Vidriera"] Torre Lujanes, 25(2005b): 45-64.

68. López-Muñoz et al., Rev. Neurol. 46(2008), 489-501. 


\section{A Psychoanalytic Approach to the Cervantine Texts}

We finally remark another aspect of the Freud-Cervantes relationship that has been addressed by some authors ${ }^{69}$, and which is the study of Cervantes's works, especially Don Quixote, from a psychoanalytic perspective. Although this is not the main aim of this study, these authors have carried out a thorough analysis of the quixotic characters from multiple perspectives: the dreams of Don Quixote; the lack of data from his childhood and a possible unresolved Oedipus complex; his obsessions and neuroses, which are, at different times, sublimated or repressed; his strong narcissistic character, overcome by a "humiliation cure;" his crush and sexual relationship with Dulcinea; the change of name provided by the character himself $\left(-\right.$ ano $^{70}$ nominal suffix, for - ote $\left.^{71}\right)$ as an example of sexual repression and the step from "anal" to "genitalia"; the interventions for sabotage at fifth-columnists by Alonso Quijano in the fantasy world of Don Quixote; the sadistic side of the protagonist exhibited through his continuous episodes of aggression; his primary masochistic nature, identified as the death instinct or "Thanatos"; the fact of getting out to the world of adventure through the back door of the house; Quijano's decision about being Rocinante the one choosing his destiny; and so on.

For the advocates of psychoanalysis, the relationship between Quijano and Sancho Panza, as well as the one between Cipion and Berganza, is endowed with rich hues. As it has been previously discussed, Sancho Panza himself, together with Alonso Quijano, could be diagnosed of "folie à deux"72. Under the current psychiatric nosology (DSM-V) Alonso Quijano arguably meets the criteria for delusional disorder and Sancho Panza would do so for shared psychotic disorder, subtype "folie impose" or induced delusional disorder ${ }^{73}$. In this relationship, Alonso Quijano keeps the dominant subject role, characterized by a more robust and cultivated personality, while Sancho Panza acquires the submissive subject role, characterized by a dependent and suggestible personality: "so keenly asserted Don Quixote that they were armies [to herds of sheep], that Sancho came to believe it" ${ }^{74}$. Cervantes himself gets this thought in the mouth of the guy who insults Don Quixote in Barcelona: "You are mad, and should you be by yourself and within the walls of your madness, were it less harm; but you have the ability to turn mad and fool those that deal and communicate with you..." ${ }^{75}$.

69. C.B. Johnson, Madness and Lust: A Psychoanalytical Approach to Don Quixote (Berkeley, University of California Press, 1983); Beá, and Hernández, Int. J. Psychoanal. 65(1984): 141-153; J.T. Abraham, "Symbolism in the cave of Montesinos," Trans. Wis. Acad. Sci. Arts Lett. 80(1992): 51-56.; Riley, Bull. Cervantes Soc. Am. 14(1994): 3-18; Parr, Bull. Cervantes Soc. Am. 15(1995): 16-25.

70. In Spanish language, "ano" means "annus".

71. In traditional Spanish, one of the popular names that the penis receives is "cipote."

72. Tabarés-Seisdedos and Corral-Márquez, Am. J. Psychiatr. 158(2001).

73. Corral-Márquez, and Tabarés-Seisdedos, Rev. Asoc. Esp. Neuropsiquiatr. 22(2003): $27-57$.

74. Cervantes, Don Quijote de la Mancha, 2004, I-XVIII.

75. Ibid., II-LVIII. 
Even several passages of Don Quixote can be explained in terms of symbolic expressions characterized by a deep psychoanalysis, as the relationship between Rocinante and the mares of Yangüesans ${ }^{76}$, or the Cave of Montesinos episode ${ }^{77}$. Specifically, Bea and Hernández consider that the mental disorder of Alonso Quijano begins when the character faces the fear of approaching old age and death, so that the internal conflicts generated by not overcome duels are the source stimulus for creativity and imagination ${ }^{78}$.

Similarly, some authors have attempted to find in The Dialogue of the Dogs the construction of the psychoanalytic dialogue that Freud subsequently defended, with all its components ${ }^{79}$ : free associations, freedom in choosing the diction of the speech, starting the discourse in the first moments of life, unconscious projections, tactical simulations, continuous repetitions, negative transfers, parent-child interactions, the myth of Ulysses, magical thinking, the power of hallucinations, the principle of reality, sublimation processes, etc.

In short, all the topics in the Freudian universe appear in Cervantes' books in one way or another.

\section{Conclusion}

José Balza emphasizes that although Cervantes never read Freud, and all these themes are properly cervantinos, they were also typical in the universe of Freud. It is clear that Freud read Cervantes (and in Castilian) ${ }^{80}$. So, we can say that Cervantes, The Dialogue of the Dogs and Don Quixote, may have played a relevant role in some psychological theories and hypotheses subsequently raised by the creator of psychoanalysis, although possibly this role was not so decisive as some authors seem to highlight.

However, we must also make clear that reading Cervantine texts from a medical perspective in general, and a psychiatric perspective in particular, may involve a series of risks that could alter the outcome of the analysis sought. Among these, we want primarily highlight the creative risk. At this point, we should remember that Cervantes' works are mere novels and not scientific texts, so that the approaches to the novels from the perspective of science only can be weakly sustained by speculative pillars. Santiago Ramón y Cajal also echoes this risk, commenting that "let us admire Cervantes' book, but do not derive its moral towards domains to which the intention of the author did not reach"81; or more recently, the poet Vicente Gaos (1919-1980), in his critical edition of Don Quixote: "psychiatrists and other critics who judge

76. Ibid., I-XV.

77. Ibid., II-XXII.; Abraham, Trans. Wis. Acad. Sci. Arts Lett. 80(1992): 51-56.

78. Beá and Hernández, Int. J. Psychoanal. 65(1984): 141-153.

79. M.L. Morales, "El 'Coloquio de los perros', desde un punto de vista psicoanalítico" ["The 'Colloquium of dogs', from a psychoanalytic point of view"]. 1616 An. Soc. Esp. Lit. Gen. Comp. 5(1983): 81-88.

80. J. Balza, "Cervantes y la narrativa contemporánea" ["Cervantes and The Contemporary Narrative"], Rev. Est. Cervantinos. 7(2008). http://bit.ly/2riSTIa

81. S. Ramón y Cajal, Psicología de don Quijote y el quijotismo [Don Quixote's Psychology and the Quixotism], Discourse, May 9, 1905 (Madrid: N. Moya), 28. 
Don Quixote schizophrenic, paranoid, etc., whether consciously or not, make the same mistake as the character they study: they confuse reality with fiction" ${ }^{82}$.

\section{Bibliography}

Abraham, J. T. "Symbolism in the cave of Montesinos." Trans. Wis. Acad. Sci. Arts Lett. 80(1992): 51-56.

Alonso-Fernández, F. El Quijote y su laberinto vital [The Quixote and his vital labyrinth]. Barcelona: Ed. Anthropos, 2005a.

Alonso-Fernández, F. "Dos especies psicopatológicas: Don Quijote y el licenciado Vidriera" ["Two psychopathological species: Don Quixote and Licentiate Vidriera"]. Torre Lujanes. 25(2005b): 45-64.

Balza, J. "Cervantes y la narrativa contemporánea" ["Cervantes and The

Contemporary Narrative"]. Rev. Est. Cervantinos. 7(2008). http://bit.ly/2riSTIa

Bailón, J.M. Un modelo de depresión neurótica en la obra de Cervantes: El curioso impertinente ["A model of neurotic depression in the work of Cervantes: 'El curioso impertinente'"]. In Actas del II Congreso Internacional de la Asociación de Cervantistas. Naples: Sociedad Edítrice Intercontinentale Gallo, 1995.

Bailón, J.M. La Psiquiatría en El Quijote. El diagnóstico de ayer y de hoy [Psychiatry in Don Quijote. The diagnosis of yesterday and today]. Barcelona: Ars Medica, 2006.

Barbier, D. Don Quichottisme et psychiatrie [Don Quixotism and psychiatry]. (Paris: Privat, 1987).

Beá, J., and Hernández, V. "Don Quixote: Freud and Cervantes." Int. J. Psychoanal. 65(1984): 141-153.

Breger, L. Freud. El genio y sus sombras [Freud. The genius and its Shadows]. Buenos Aires: Ediciones B, 2001.

Canavaggio, J. Cervantes. En busca del perfil perdido [Cervantes. In search of the lost profile], $2^{\text {nd }}$ ed.. Madrid: Espasa-Calpe 1992.

Carpintero, H. and Mestre, M.V. Freud en España [Freud in Spain]. Valencia: Promolibro, 1984.

Cervantes, M. Novelas ejemplares, II [Exemplary Novels, II]. H. Sieber (ed.). Madrid: Cátedra, 2003.

Cervantes, M. Don Quijote de la Mancha, F. Rico (ed.). Madrid: Santillana, 2004.

Chávez, C. "El Quijote y El coloquio de los perros: origen inconsciente del psicoanálisis" ["Don Quixote and The colloquium of dogs: unconscious origin of psychoanalysis"]. In XIX Coloquio Cervantino Internacional. El Quijote, perspectiva del siglo XXI. Guanajuato, Mexico, November 4-8, 2008.

Corral-Márquez, R., and Tabarés-Seisdedos, R. "Aproximación psicopatológica a El Quijote (según la nosología psiquiátrica actual)" ["Psychopathological Approach to Don Quixote (according to current psychiatric nosology) "]. Rev. Asoc. Esp. Neuropsiquiatr. 22(2003): 27-57.

Couleon, H. "L'étrange folie de Don Quichotte. Cervantes et la psychiatrie" ["The strange madness od D. Quixote. Cervantes and Psychiatry"]. Ann. Méd-Psychol. 122(1964): 555-566.

82. V. Gaos, Edición crítica y comentarios a "El ingenioso hidalgo Don Quijote de la Mancha", de Miguel de Cervantes Saavedra [Critic Edition and Comments to 'Don Quixote', from Miguel de Cervantes Saavedra] (Madrid: Gredos, 1987), 162. 
Eisenberg, D. Vida de Cervantes [Life of Cervantes]. Alicante: Biblioteca Virtual Miguel de Cervantes, 2003.

Fitzmaurice-Kelly, J. Miguel de Cervantes Saavedra. Reseña documentada de su vida. (1980). http://bit.ly/2qBmOY7.

Freud, S. El chiste y su relación con lo inconsciente. Madrid: Alianza, 1905-2012.

Freud, S. "Psicopatología de la vida cotidiana." Obras completas, vol 3, XX. Madrid: Biblioteca Nueva, 1905-1997.

Freud, S. Totem y tabú [Totem and taboo]. Madrid: Alianza, 1913-2013.

Freud, S. Obras completas [Complete works]. Madrid, España: Biblioteca Nueva, 1923/1968.

Freud, S. Cartas a la novia [The bridal Letters] (1882-1886). Barcelona: Tusquets, 1973.

Freud, S. Cartas de juventud [The youth letters] (1871-1881). Barcelona: Gedisa, 1992.

Freud, S. Autobiografía [Autobiography]. Madrid, España: Alianza, 2006.

Freud, S. Cartas a Wilhelm Fliess [Letters to Wilhelm Fliess] (1887-1904). Buenos Aires, Argentina / Madrid, España: Amorrortu, 2008.

Gaos, V. Edición crítica y comentarios a "El ingenioso hidalgo Don Quijote de la Mancha", de Miguel de Cervantes Saavedra [Critic Edition and Comments to 'Don Quixote', from Miguel de Cervantes Saavedra]. Madrid: Gredos, 1987.

Gay, P. Freud. Una vida de nuestro tiempo [Freud. A life of our Time]. Barcelona: Paidós, 1989.

Gómez, C. La realidad y la ilusión: Cervantes en Freud [Reality and Illusion: Cervantes in Freud]. An. Sem. Hist. Fil. 24(2007): 195-214.

Goyanes Capdevila, J. Tipología de El Quijote. Ensayo sobre la estructura psicosomática de los personajes de la novela [Typology of Don Quixote. Essay on the psychosomatic structure of the characters of the novel]. Madrid, España: Imprenta S. Aguirre, 1932.

Gracia, D. "Discretas locuras. Variaciones en torno al tema de la locura de Don Quijote Quijote" ["Discreet foolishness. Variations around the subject of the madness of Don Quixote"]. In III y IV Centenario de El Quijote en la Real Academia Nacional de Medicina. Madrid: Ed. Real Academia Nacional de Medicina, 2005.

Grinberg, L., and Rodríguez, J.F. "La influencia de Cervantes sobre el futuro creador del psicoanálisis" ["The influence of Cervantes on the future creator of psychoanalysis"]. An. Cervantinos, 25-26(1987-1988): 157-174.

Hernández Morejón, A. Bellezas de medicina práctica descubiertas en el Ingenioso Hidalgo Don Quijote de La Mancha [Beauties of practical medicine discovered in the Ingenious Hidalgo Don Quixote of La Mancha]. Madrid: Imprenta de Tomás Jordán, 1836.

Johnson, C.B. Madness and Lust: A Psychoanalytical Approach to Don Quixote. Berkeley: University of California Press, 1983.

Jones, E. Vida y obra de Sigmund Freud [Life and works of Sigmund Freud]. Buenos Aires: Nova, 1962.

Labastida, J. "El Quijote lee a Kant, Hegel, Freud y Lacan" ["Quixote reads Kant, Hegel, Freud and Lacan"]. In Memorias de la Academia Mexicana de la Lengua, vol. XXVII (1997-1999). Mexico: Academia Mexicana de la Lengua, 2004.

López-Muñoz, F., \& Álamo, C., (Eds.). Historia de la Psicofarmacología [History of Psychopharmacology], 3 vls. Madrid: Editorial Médica Panamericana, S.A, 2007.

López-Muñoz, F., Rubio, G., Álamo, C., and García-García, P.A propósito de la locura del hidalgo Alonso Quijano en el marco de la medicina española tardorrenacentista [On the subject of the madness of the hidalgo Alonso Quijano 
in the frame of the Spanish medicine of the late Renaissance]. An. Psiquiatr. 22(2006): 133-145.

López-Muñoz, F., Álamo, C., and García-García, P. Locos y dementes en la literatura cervantina: a propósito de las fuentes médicas de Cervantes en materia neuropsiquiátrica. Rev. Neurol. 46(2008), 489-501.

López-Muñoz, F., Álamo, C., and Domino, E.F. (Eds.). History of Psychopharmacology, 4 vls. Arlington (MA), USA: NPP Books, 2014.

Morales, M.L. "El "Coloquio de los perros", desde un punto de vista psicoanalítico." ["The 'Colloquium of dogs', from a psychoanalytic point of view"]. 1616. An. Soc. Esp. Lit. Gen. Comp. 5(1983): 81-88.

Moreno, M.R. "Un original coloquio. Desde el Jardín de Freud" ["An original colloquium. From Freud`s Garden"]. Rev. Psicoanál. 6(2006): 272-281.

Parr, J.A. Cervantes foreshadows Freud: On Don Quixote's Flight from the feminine and the physical. Bull. Cervantes Soc. Am. 15(1995): 16-25.

Pi i Molist, E. Primores de don Quijote en el concepto médico-psicológico y consideraciones generales sobre la locura para un nuevo comentario de la inmortal novella [Primors of Don Quixote in the medical-psychological concept and general considerations on insanity for a new commentary on the immortal novel]. Barcelona: Imprenta Barcelonesa, 1886.

Ramón y Cajal, S. Psicología de don Quijote y el quijotismo [Don Quixote's Psychology and the Quixotism]. Discourse, May 9, 1905. Madrid: N. Moya.

Riley, E.C. Cervantes, Freud and psychoanalytic narrative theory. Modern Lang. Rev. 88(1993): 1-14.

Riley, E.C. "Cipión Writes to Berganza in the Freudian Academia Española." Bull. Cervantes Soc. Am. 14(1994): 3-18.

Royo Villanova, R. "La locura de Don Quijote. Discurso de apertura de la Academia Médico Quirúrgica aragonesa, 1905". In III y IV Centenario de El Quijote en la Real Academia Nacional de Medicina. Madrid: Ed. Real Academia Nacional de Medicina, 2005.

Sánchez-Grangel, L. "Lectura médica de El Quijote" ["Medical Reading of Don Quixote"]. In III y IV Centenario de El Quijote en la Real Academia Nacional de Medicina. Madrid: Ed. Real Academia Nacional de Medicina, 2005.

Tabarés-Seisdedos, R., and Corral-Márquez, R. "Miguel de Cervantes, 1647-1616". Am. J. Psychiatr. 158(2001): 1392.

Vranich, S.B. "Sigmund Freud and 'the case history of Berganza': Freud's psychoanalytic beginnings." Psychoanal. Rev. 63(1976): 73-82.

Wolman, B. Teorías y sistemas contemporáneos en psicología [Contemporary theories and systems in psychology]. Barcelona: Martínez-Roca, 1968.

Zweig, S. La curación por el espíritu [Healing by the Spirit]. Barcelona: Editorial Acantilado, 2006. 